\title{
Prevalence of Noise-induced Hearing Loss in Cotton Ginning Factories in Parakou, North Benin
}

\author{
Hounkpatin Spéro Herménégilde Raoul ${ }^{1, ~ *}$, Flatin Marius Claude ${ }^{1}$, \\ Gounongbé Ahoya Christophe Fabien ${ }^{2}$, Aissi Monelle Benett Ablawa Vanessa ${ }^{1}$, \\ Bouraima Fatiou Alabi $^{1}$, Amegan Hamondji Nicolas ${ }^{3}$, Wassi Adjibabi ${ }^{4}$ \\ ${ }^{1}$ Department of Surgery and Surgical Specialties, Faculty of Medicine, University of Parakou, Parakou, Benin \\ ${ }^{2}$ Department of Medicine and Medical Specialties, Faculty of Medicine, University of Parakou, Parakou, Benin \\ ${ }^{3}$ Department of Medicine and Medical Specialties, Faculty of Health Sciences, University of Abomey-Calavi, Cotonou, Benin \\ ${ }^{4}$ Department of Surgery and Surgical Specialties, Faculty of Health Sciences, University of Abomey-Calavi, Cotonou, Benin
}

Email address:

speraoul@yahoo.fr (H. S. H. Raoul)

${ }^{*}$ Corresponding author

\section{To cite this article:}

Hounkpatin Spero Herménégilde Raoul, Flatin Marius Claude, Gounongbé Ahoya Christophe Fabien, Aissi Monelle Benett Ablawa Vanessa, Bouraima Fatiou Alabi, Amegan Hamondji Nicolas, Wassi Adjibabi. Prevalence of Noise-induced Hearing Loss in Cotton Ginning Factories in Parakou, North Benin. International Journal of Otorhinolaryngology. Vol. 5, No. 2, 2019, pp. 48-52. doi: 10.11648/j.ijo.20190502.14

Received: November 17, 2019; Accepted: December 2, 2019; Published: December 10, 2019

\begin{abstract}
This research work aimed to determine the prevalence of noise induced hearing loss by in an industrial area. It is was descriptive cross-sectional study which was carried out from March to May 2014 in three (03) cotton ginning factories located in the city of Parakou. It involved the workers exposed to noise, who had accepted to participate to the survey and in whom an audiometry was performed. One hundred and thirteen workers were selected, including $104(92 \%)$ male and 9 female (8\%). Their mean age was $39.3+/-9.6$ years with extremes of 18 and 54 years. During 8 hours a day, $38 \%$ of the respondents were exposed to noise levels lower than $80 \mathrm{~dB}(\mathrm{~A}), 31 \%$ to levels higher or equal to $90 \mathrm{~dB}(\mathrm{~A})$ and $31 \%$ to levels between 80 and $90 \mathrm{~dB}(\mathrm{~A})$. The average seniority of the workers surveyed was 7 cotton seasons with extremes of one and 31 seasons. No employee had benefitted from medical consultation or audiometry on recruitment or thereafter. And all the employees reported not using any personal protective equipment. The overall prevalence of noise induced hearing loss in the cotton ginning factories in Parakou in 2014 was estimated at $88.5 \%$ (100 out of 113 respondents). The average hearing loss (AHL) was 40.8 $\mathrm{dB}+/-8.8 \mathrm{~dB}$ in the right ear and $28.9 \mathrm{~dB}+/-11.8 \mathrm{~dB}$ in the left ear. Taking into account only the deafest ear, AHL was light in $44 \%$ of cases, moderate in $54 \%$ of cases and severe in $2 \%$ of cases. There was a statistically significant relationship between the degree of NIHL and seniority in the firm $(\mathrm{p}=0.012)$.
\end{abstract}

Keywords: Occupational Deafness, Noise, Acoustic Trauma, Industrial Environment

\section{Introduction}

Noise is a major nuisance in many sectors of professional activity. As the outcome of noise in the absence of preventive measures, occupational hearing loss is a bilateral symmetrical hearing loss. However, there is evidence that asymmetric hearing loss may also occur, although limited [1]. Workers in industry have the highest risk of hearing loss, as well as those in shipbuilding, construction industry, military and farmers [2]. The major mechanisms of noise-induced hearing loss are physical damage in organ of Corti, decreased blood flow causing the hypoxia of the inner ear, oxidative stress of reactive oxygen species, and neural degeneration in synaptic terminals of cochlear nerve fibers and spiral ganglion cells [3]. Hearing loss, characterized by an insidious onset, is often identified only when damage has become irreversible. There is no current effective treatment to regenerate damaged sensory receptors after noise exposure, leaving amplification as one of the only options [4]. Across the world, $16 \%$ of cases of disabling hearing loss in adults are attributed to noise at work place; however, sub-regional variations or disparities are noted [5]. In many developed countries, the 
preventive potential of reducing noise exposure has led to mandatory hearing loss prevention programs [4]. In Africa, there are few data on the prevalence and causes of deafness [6]. If in developed countries, morbidity associated with noise decreases with introduction of protective measures protection measures, in developing countries, the few data available suggest that average noise levels outweighed the level recommended in work places [7, 8]. Few research works are found in literature about hearing loss associated with noise in Benin $[9,10]$. The scarcity of research works on noise pollution in Benin and the need to establish a diagnosis to help take appropriate measures are an evidence of the relevance of this study. Therefore, this study aims to determine the prevalence of noise induced hearing loss (NIHL) in employees working at cotton ginning factories in Parakou which is the main city in the North-Benin. To the best of our knowledge, any study had not been conducted yet on the topic in that region.

\section{Study Methods}

This research work was a descriptive cross-sectional study carried out from March 3, 2014 to May 30, 2014 in Parakou which, due to its importance, is the third city of Benin (West Africa). It involved workers exposed to noise, in 3 cotton ginning factories. Those employees worked during the cotton production season which lasts 5 to 6 months per year. Minimum sample size was 98 ; it was determined using the Schwartz formula [11]: $\mathrm{N}=\varepsilon^{2}{ }_{\alpha} \mathrm{p}(1-\mathrm{p}) / \mathrm{i}^{2}[\mathrm{~N}$ : minimum sample size; $\varepsilon_{\alpha}=$ deviation reduced to risk $\alpha(1.96) \alpha=$ allowed risk of error (5\%); i: accuracy (5\%); p: prevalence of hearing loss ( $50 \%$ in the absence of data). The study included employees within different factories or in their immediate vicinity, who had accepted to participate to the survey and in whom an audiometry was performed. This study excluded those who had:

1. An age of 55 years or more,

2. Worked in a noisy entity before recruitment or who had a extra-professional activity or regular noisy leisure,

3. As ENT history, an otologic malformation, a personal deafness before recruitment or a notion of family deafness,

4. An abnormal otoscopy during ear, nose and throat examination as a preliminary step to audiometry.

The study variables were deafness associated with noise, mean hearing loss, sociodemographic characteristics (age and sex), socio-professional characteristics (noise exposure level, seniority, medical consultation or not on recruitment and medical follow-up, use or non-use of personal protective equipment against noise).

Pure-tone audiometry preceded by otoscopy was performed at a distance of factories, depending on weekly distribution of respondents and before starting work in order to reduce the impact that auditory fatigue may have. We retained as hearing loss associated with noise any bilateral symmetrical deafness identified during pure-tone audiometry. The same applied to perception deafness on one side and mixed hearing loss on the other side, considering that noiseinduced deafness was associated with an unknown concomitant impairment of the sound transmission apparatus. The average hearing loss (AHL) was calculated by dividing by 4 the sum of the hearing losses at frequencies 500,100 , 2000, and 4000 hertz at the most deaf ear. The degree of deafness was classified as light, moderate, severe or profound for AHL between 20 and $39 \mathrm{~dB}, 40$ and $69 \mathrm{~dB}, 70$ and $89 \mathrm{~dB}$, $90 \mathrm{~dB}$ and above respectively.

The noise exposure level by work station was measured using a digital KOOLERTRON SL1361 sonometer, measuring noises of 30-130 dB and equipped with a memory card

The data were entered using EPI-DATA software. SPSS statistical software (21) was used for data audit and processing. Comparisons were made using $\mathrm{chi}^{2}$ test. Significance level was 5\%.

\section{Findings}

On this basis, 113 workers exposed to noise were selected using simple random sampling among a list of employees in each of the three factories, in proportion to their number.

\subsection{Sex and Age}

Among the 113 respondents, 104 were male (92\%) and 9 were female (8\%). Mean age for those respondents was 39.3 $+/-9.6$ with extremes from 18 and 54 years. Figure 1 summarized the distribution of survey population according to age.

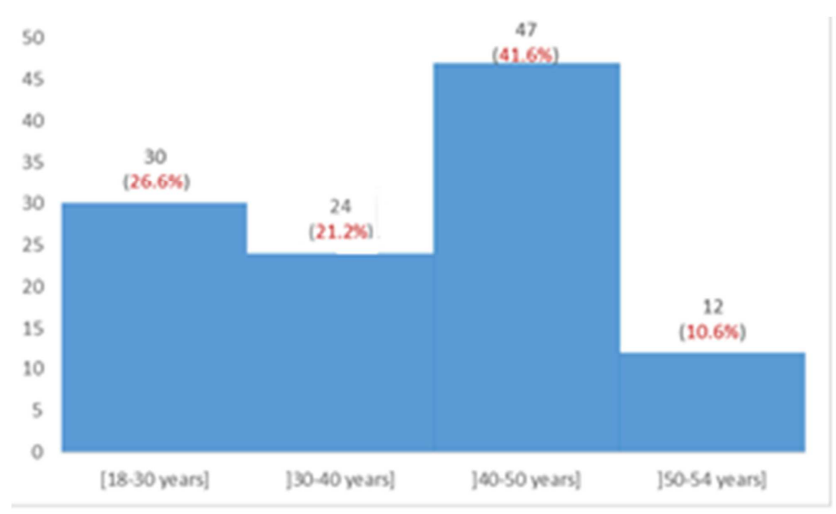

Figure 1. Distribution of respondents by age group, Parakou 2014.

\subsection{Sound Characteristics in the Factories}

The type of noise was identical, continuous and fluctuating for all work stations in the three factories. Noise intensity varied from 54 to $105.4 \mathrm{~dB}$ (A) depending on work stations with an average of $79.1 \mathrm{~dB}(\mathrm{~A})+/-14.5$.

\subsection{Professional Characteristics}

\subsubsection{Seniority in the Company}

Of the 113 workers surveyed, $44.3 \%$ were in their first season and $11.4 \%$ had seniority of 10 or more seasons. The average seniority of the workers surveyed was 7 seasons with extremes of one and 31 seasons. Figure 2 summarizes the 
distribution of the study population by seniority in number of seasons.

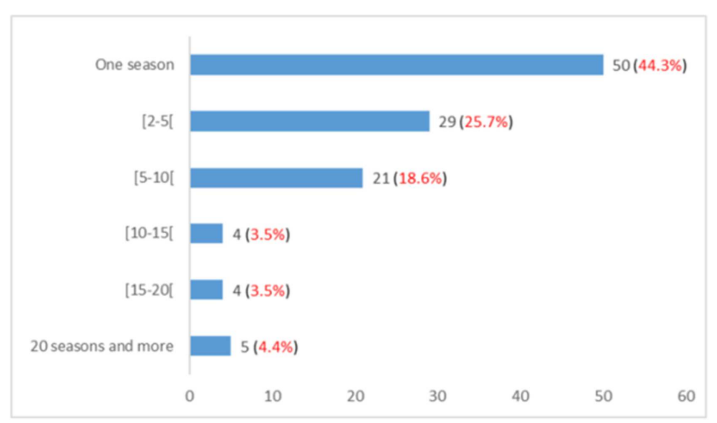

Figure 2. Distribution of respondents by seniority in number of seasons, Parakou 2014.

\subsubsection{Work Duration and Exposure to Noise}

According to work organization in the factory $(3 \times 8$ hour system or 4 x 8 hour system), $72.6 \%$ of the employees worked during approximately 48 hours per week. $27.4 \%$ worked during nearly 56 hours per week, thus an addition of 8 hours. Most of them (93.8\%) reported they were exposed to noise during approximately 8 hours a day. One employee said he worked during more than 8 hours a day and 6 employees $(5.3 \%)$ claimed to be exposed during less than 8 hours a day.

\subsubsection{Medical Visits and Individual Preventive Measures}

No employee had benefitted from medical consultation or audiometry on recruitment or thereafter and all reported they did not use any personal protective equipment.

\subsection{Prevalence NIHL Among Workers Investigated as Respondents}

\subsubsection{Results of the Audiometry}

During audiometry, 2 subjects had a normal audition, 11 had deafness that may not be associated with noise and 100 had hearing loss likely to be associated with noise considering our inclusion criteria. Figure 3 summarizes the distribution of investigated population according to audiometry results.

Shl. sensorineural hearing loss Chl. Conductive hearing loss Mhl. Mixed hearing loss

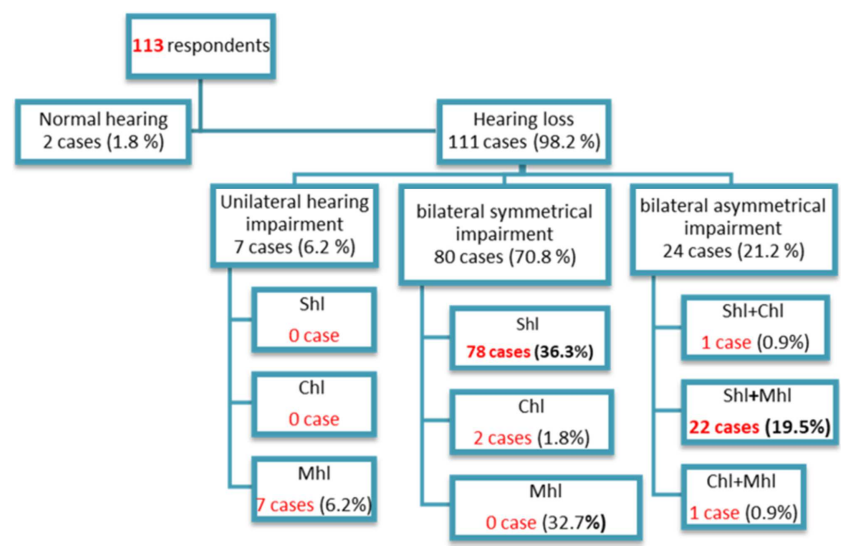

Figure 3. Distribution of the investigated population according to total audiometry results, Parakou 2014.
The overall prevalence of noise-induced deafness in industrial areas in Parakou in 2014 was estimated at $88.5 \%$ (100 out of 113 respondents).

\subsubsection{Degree of Noise-related Hearing Loss and Seniority}

Taking into account only the deafest ear, MAP was light in $44 \%$ of cases, moderate in $54 \%$ of cases and severe in $2 \%$ of cases. There was a statistically significant relationship between the degree of noise-related hearing loss and seniority in the firm $(p=0.012)$.

Table 1. Distribution of respondents according to the degree of noise-related hearing loss and seniority in the firm, Parakou 2014.

\begin{tabular}{llllll}
\hline & Light & Medium & Severe & Total & $\boldsymbol{p}$ \\
\hline & & & & & 0.012 \\
One season & 16 & 28 & 1 & 45 & \\
{$[2-5]$} & 14 & 9 & 0 & 23 & \\
{$[5-10]$} & 9 & 11 & 0 & 20 & \\
{$[10-15]$} & 3 & 1 & 0 & 4 & \\
{$[15-20]$} & 1 & 1 & 1 & 3 & \\
20 seasons and more & 1 & 4 & 0 & 5 & \\
Total & 44 & 54 & 2 & 100 & \\
\hline
\end{tabular}

\section{Discussion}

Noise is harmful to human health; its impact consists of effects on audition likely to lead to deafness and subjective or objective extra-auditory effects. The sources of noise are innumerable and diversified depending on the environment. In the work place, exposure to noise varies depending on activities carried out and material used on the work site. For one working day ( 8 hours), it is considered that hearing is at risk as from $80 \mathrm{~dB}(\mathrm{~A})$; this is the risk warning threshold for sound level monitoring and staff information. $85 \mathrm{~dB}(\mathrm{~A})$ is the hazard score for implementing staff prevention and protection measures [12, 13]. In 2014, within the cotton ginning factories located in Parakou, noise level varied from 54 to $105.4 \mathrm{~dB}$ (A) among the workers investigated. In Ghana, Kitcher E. et al. [14] reported in 2014 that condiment mill workers operating in markets were exposed to ambient noise levels ranging from 85.9 to $110.8 \mathrm{~dB}$ (A). Every year, 22 million workers are exposed to dangerous noise or sound levels in the United States [15]. In India, Singh L. et al. [16] had reported in 2013 average sound levels which vary from 89.4 to $105.10 \mathrm{~dB}$ (A) depending on the work station in a steel industry; prevalence of hearing loss associated with noise was estimated at more than $90 \%$ among workers. The prevalence of noise-related hearing loss among workers of cotton ginning factories in Parakou was very high $(88.5 \%)$ but less elevated compared to those of Singh et al. (90\%) [16]. In contrast, prevalences less high than in Parakou had been reported by several authors. For instance, in Malaysia, Ahmad et al. [17] had reported in 2013 a 57\% prevalence of hearing loss due to noise among quarry workers. In Africa, there are few data on the prevalence of NIHL at work place [18]. In Ghana, Kitcher et al. [14] had found in 2014 twentyfour decimal eight percent $(24.8 \%)$ of hearing loss among condiment mill workers operating in markets. In Nigeria, Ologe et al. [19] had found in 2006 among 103 workers of a 
rolling mill exposed to noise levels ranging from 49 to 93 dBA; nearly $28.2 \%$ of people presented with sensorineural hearing loss in their best ear and $56.8 \%$ presented with sensorineural hearing loss in their worse ear. In Zimbabwe, Chadambuka et al. [20] had identified in 2013 a $36.7 \%$ prevalence of hearing loss in the 169 workers of a mining industry, although $140(82.8 \%)$ among them reported they used hearing protection devices. The diversity of those different prevalence rates may be due to many reasons, including workers' selection criteria, differences between ambient noise levels which are likely to vary from a work place to another work place and from a work station to another in the same work environment, and duration of noise exposure. In the textile industries, a high incidence of hearing loss was often observed among the workers [21-24]. The probable reason of such observation is an excessive exposure to noise in that industrial sector $[22,25]$. Different uses of protection individual measures are other reason for discrepancy between prevalence rates. In Ghana, 5\% of condiment mill workers operating in markets used personal protective equipment whereas this prevention equipment is not available in Parakou [15]. In India, 5\% of workers of steel industries said they always used their noise cancelling devices versus $60 \%$ who never used them and the rest used them on a more or less regular basis [16]. A study carried out in South Africa among mining workers found that less than half of them regularly wore noise cancelling devices; however, almost all of them said they knew the importance of using those hearing protection devices [26]. One of the problems raised by the use of personal protective equipment by workers is compliance with their use conditions. This implies not only willingness but also awareness among workers about the value and necessity of wearing the said equipment permanently during whole period of noise exposure.

The use of personal protective equipment does not exclude occurrence of hearing losses $[27,28]$. Nonetheless, the said equipment would mitigate their magnitude [29, 30]. An efficient prevention of NIHL involves using that personal equipment with instructions for proper use in combination with programmes for the prevention of hearing loss due to "clear noises" [28]. Moreover, a periodic audiometric monitoring of workers exposed to high ambient sound levels is recommended to be integrated among ear protection measures [31-33]. In this study conducted in Parakou, no employee on work site underwent recruitment medical examinations or annual medical examinations. No audiometry had been performed. The lack of follow-up and control by relevant authorities is a factor that may explain this situation.

\section{Conclusion}

Hearing impairments, caused by noise annoyance in industrial areas in the District of Parakou in 2014, are a reality. The absence of preventive measures is notable while hearing loss is usually characterized by an insidious onset.
All the stakeholders involved in that work environment should participate in the actual prevention of occupational deafness. Pending further studies to specify the particularities of hearing loss associated with noise in our context, some measures should be taken by political and administrative authorities to ensure the proper enforcement of applicable mandatory regulations related to workers' protection.

\section{References}

[1] Le TN, Straatman LV, Lea J, Westerberg B. Current insights in noise-induced hearing loss: a literature review of the underlying mechanism, pathophysiology, asymmetry, and management options. Journal of Otolaryngology - Head and Neck Surgery (2017) 46: 41. DOI 10.1186/s40463-017-0219$\mathrm{x}$.

[2] Lie A, Skogstad M, Johannessen HA, Tynes T, Mehlum IS, Nordby KC, Engdahl B, Tambs K. Exposition au bruit et audition au travail: une revue systématique. Int Arch Occup Environ Santé. 2016 Avril; 89 (3): 351-72. doi: 10.1007/s00420-015-1083-5.

[3] Yang CJ, Chung JW. Physiopathologie de la perte d'audition due au bruit. Audiology and Speech Research 2016; 12 (Supp11): S14-S16.

[4] Verbeek JH, Kateman E, Morata TC, Dreschler WA, Mischke C. Interventions to prevent occupational noise-induced hearing loss: A Cochrane systematic review. Int J Audiol. 2014 Mar; 53 (2): S84-S96. doi: 10.3109/14992027.2013.857436.

[5] Nelson DI, Nelson RY, Concha-Barrientos M, Fingerhut M. The global burden of occupational noise-induced hearing loss. Am J Ind Med. 2005; 48 (6): 446-58.

[6] W. Mulwafu, H. Kuper, R. J. H. Ensink. Prevalence and causes of hearing impairment in Africa. Tropical Medicine and International Health 2016. 21 (2): 158-165. doi: 10.1111/tmi. 12640

[7] Concha-Barrientos M, Campbell-Lendrum D, Steenland K. Occupational noise. Assessing the burden of disease from work-related hearing impairment at national and local levels. environmental burden of disease series, $\mathrm{n}^{\circ} 9$, World health Organization, geneva, 2004; 41p.

[8] Graydon K, Waterworth C, Miller H, Gunasekera H. Global burden of hearing impairment and ear disease. J Laryngol Otol 2019; 133: 18-25. https://doi.org/10.1017/S0022215118001275.

[9] Hinson A. V, Lawin H, Gounongbé F, Aguemon B, AmiTouré R, Gnonlonfoun D. Évaluation des nuisances sonores chez les travailleurs d'une société de production d'acier au Bénin. Cahiers de Médecine InterProfessionnelle 2017. 1, 2: 1-16. disponible sur le site: http://www.camip.info/etudes-etrecherches/numeros-precedents/2017-448/camip-2017-12/evaluation-des-nuisances-sonores/article/versionimprimable-5575 consulté le 8/9/2018.

[10] Ayelo AP, Aguemon B, Hinson AV, Yedomon B, Afokpa K. Atteintes auditives chez les ferblantiers du secteur informel à Cotonou. Archives des Maladies Professionnelles et de

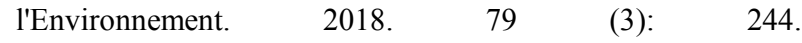
https://doi.org/10.1016/j.admp.2018.03.054. 
[11] Schwartz D. Méthodes statistiques à l'usage des médecins et biologistes, ed. Flammarion Médecins Sciences, 1969.

[12] Agence française de sécurité sanitaire environnementale. Impacts sanitaires du bruit: État des lieux, Indicateurs bruitsanté. 2004. $157 \mathrm{p}$ disponible sur https://www.anses.fr/fr/system/files/AP2003et1000Ra.pdf consulté le 14/9/2018.

[13] Institut National de Recherche et Sécurité. Dossier bruit.disponible sur https://www.vdmconsulting.fr/site $\% 20 \mathrm{vdm} /$ documents/Bruit.pdf consulté le14 19/2018; Mission Santé-sécurité au travail dans les fonctions publiques. Le bruit. disponible sur http://www.intefpsstfp.travail.gouv.fr/datas/files/SSTFP/5\%20Bruit.pdf consulté le $19 / 9 / 2018$.

[14] Kitcher ED, Ocansey G, Abaidoo B, Atule A. Occupational hearing loss of market mill workers in the city of Accra, Ghana. Noise Health. 2014 Jun 20; 16 (70): 183-8.

[15] The National Institute for Occupational Safety an Health (NIOSH). Occupational hearing loss (OHL) surveillance. disponible sur le site: https://www.cdc.gov/niosh/topics/ohl/ consulté le 17/9/7018.

[16] Singh LP, Bhardwaj A, Deepak K. Occupational noiseinduced hearing loss in Indian steel industry workers: an exploratory study. Hum Factors. 2013; 55 (2): 411-24.

[17] Ahmad F, Aziah D, Zaliha I, Baharudin A. Noise-Induced Hearing Loss Among Quarry Workers in a North-Eastern State of Malaysia: A Study on Knowledge, Attitude and Practice. Oman Médical Journal. 2013; 28 (5): 331-6.

[18] Moroe N, Khoza-Shangase K, Kanji A, Ntlhakana L. The management of occupational noise-induced hearing loss in the mining sector in Africa: A systematic review - 1994 to 2016. Noise \& Vibration Worldwide 2018. 49 (5): 181-190.

[19] Ologe FE, Akande TM, Olajide TG. Occupational noise exposure and sensorineural hearing loss among workers of a steel rolling mill. Eur Arch Otorhinolaryngol. 2006; 263 (7): 618-21.

[20] Chadambuka A, Mususa F, Muteti S. Prevalence of noise induced hearing loss among employees at a mining industry in Zimbabwe. Afr Health Sci. Dec 2013; 13 (4): 899-906.

[21] Nada E, Ebraheem WM, Sheta S. Noise-induced hearing loss among workers in textile factory. Egypt J Otolaryngol 2014; 30: $243-8$

[22] Shahid A, Jamali T, Kadir MM (2018) Noise Induced Hearing Loss among an Occupational Group of Textile Workers in Karachi, Pakistan. Occup Med Health Aff 6: 282. DOI: 10.4172/2329-6879.1000282.
[23] Sacko HB, Coulibaly MB, Traoré T, Telly N, Coulibaly S, Sanogo H, Fane S, Bagayogo HD, Bouaré M. Audiometric Findings of Textile Workers in Mali. Otolaryngology Online Journal (2016). $\mathrm{http}: / / w w w . a l l i e d a c a d e m i e s . o r g / a r t i c l e s / a u d i o m e t r i c-f i n d i n g s-$ of-textile-workers-in-mali.html

[24] Nandi SS, Dhatrak SV. Occupational noise-induced hearing loss in India. Indian J Occup Environ Med. 2008. 12 (2): 5356. doi: 10.4103/0019-5278.43260.

[25] Caldart AU, Adriano CF, Terruel I, Martins RF, Caldart AU, Mocellin M. La prévalence de la perte d'audition due au bruit chez les travailleurs de l'industrie textile. International archives of Otorhinolaryngology 2006. 10 (3) disponible sur http://arquivosdeorl.org.br/additional/acervo_eng.asp?id=380

[26] Kanji A, Khoza-Shangase K, Ntlhakana L. Noise-induced hearing loss: what South African mineworkers know. International Journal of Occupational Safety and Ergonomics, 25: 2, 305-310, DOI: 10.1080/10803548.2017.1412122.

[27] Seixas S, Goldman B, Sheppard L, Neitzel R, Norton S, Kujawa S. Prospective noise induced changes to hearing among construction industry apprentices. Occup Environ Med 2005; 62: 309-17.

[28] Tikka C, Verbeek JH, Kateman E, Morata TC, Dreschler WA, Ferrite S. Interventions to prevent occujpational noise-induced hearing loss. Cochrane Database of Systematic Reviews 2017. 7. DOI: $10.1002 / 14651858 . C D 006396 . p u b 4$.

[29] McTague M, Galusha D, Dixon-Ernst C et al. Impact of Daily Noise Exposure Monitoring on Occupational Noise Exposures in Manufacturing Workers. Int J Audiol. 2013; 01; 52 (01): S3-S8.

[30] Hong O. Hearing loss among operating engineers in American construction industry. Int Arch Occup Environ Health 2005. 14; 78: 565-74.

[31] Fausti SA, Wilmington DJ, Helt PV, Helt WJ, Konrad-Martin $\mathrm{D}$, The need for improved hearing loss prevention and hearing conservation practices Journal of Rehabilitation Research \& Development Hearing health and care 2005. 42 (4): 45-62.

[32] Somma G, Pietroiusti A, Magrini A, Coppeta L, Ancona C, Gardi S, Messina M, Bergamaschi A. Extended highfrequency audiometry and noise induced hearing loss in cement workers. American Journal of Industrial Medicine 2008. 51: 452-462.

[33] Hong O, Kerr MJ, Poling GL, Dhar S. Understanding and preventing noise-induced hearing loss. Disease-a-Month 2013. 59: 110-118. 